\title{
Role of Oral Microbiota in Cancer Development
}

\author{
Tomasz M. Karpiński (D) \\ Department of Medical Microbiology, Poznań University of Medical Sciences, Wieniawskiego 3, \\ 61-712 Poznań, Poland; tkarpin@ump.edu.pl or tkarpin@interia.pl; Tel.: +48-61-854-61-38
}

Received: 29 December 2018; Accepted: 11 January 2019; Published: 13 January 2019

\begin{abstract}
Nowadays cancer is the second main cause of death in the world. The most known bacterial carcinogen is Helicobacter pylori. Pathogens that can have an impact on cancer development in the gastrointestinal tract are also found in the oral cavity. Some specific species have been identified that correlate strongly with oral cancer, such as Streptococcus sp., Peptostreptococcus sp., Prevotella sp., Fusobacterium sp., Porphyromonas gingivalis, and Capnocytophaga gingivalis. Many works have also shown that the oral periopathogens Fusobacterium nucleatum and Porphyromonas gingivalis play an important role in the development of colorectal and pancreatic cancer. Three mechanisms of action have been suggested in regard to the role of oral microbiota in the pathogenesis of cancer. The first is bacterial stimulation of chronic inflammation. Inflammatory mediators produced in this process cause or facilitate cell proliferation, mutagenesis, oncogene activation, and angiogenesis. The second mechanism attributed to bacteria that may influence the pathogenesis of cancers by affecting cell proliferation is the activation of NF- $\mathrm{KB}$ and inhibition of cellular apoptosis. In the third mechanism, bacteria produce some substances that act in a carcinogenic manner. This review presents potentially oncogenic oral bacteria and possible mechanisms of their action on the carcinogenesis of human cells.
\end{abstract}

Keywords: oral microbiota; oral cancer; colorectal cancer; Porphyromonas gingivalis; Fusobacterium nucleatum; Streptococcus sp.; chronic inflammation; antiapoptotic activity; cancerogenic substances

\section{Introduction}

Nowadays cancer is the second main cause of death in the world. It is estimated that in 2018 about 9.6 million people will have died from cancer. Among men, the most common types of cancers are lung, prostate, colorectal, and stomach cancers, while among women the most common are breast, colorectal, lung, and cervix cancers [1]. Cancer of the oral cavity is one of the most common malignancies [2]. According to the World Health Organization (WHO), there are an estimated 657,000 new cases of cancers of the oral cavity and pharynx each year, and more than 330,000 deaths [3]. Oral squamous cell carcinomas (OSCCs) constitute more than $90 \%$ of oral and oropharyngeal cancer and the main etiological factor is the synergistic effect of tobacco and alcohol use [4].

The most well-known bacterium associated with the development of cancer in humans is Helicobacter pylori, which is defined as a class I carcinogen [5]. H. pylori is an etiological agent of peptic ulcer disease, chronic gastritis, gastric adenocarcinoma, and gastric mucosa-associated lymphoid tissue (MALT) lymphoma, with intestinal metaplasia [6]. At the same time, there are data suggesting the role of oral cavity bacteria in the development of cancer. Such bacteria can be responsible for oral cancers, as well as tumors of the gastrointestinal tract. Some specific bacteria have been identified that correlate strongly with OSCCs, such as Streptococcus sp., Peptostreptococcus sp., Prevotella sp., Porphyromonas gingivalis, and Capnocytophaga gingivalis [7-13]. Oral cancer and epithelial precursor lesions are also linked with bacteria from genera Fusobacterium, Veillonella, Actinomyces, Clostridium, Haemophilus, and Enterobacteriaceae [14]. Many works have also shown that oral pathogens are essential in the development of colorectal and pancreatic cancer. Two periopathogenic species in particular have been frequently mentioned: Fusobacterium nucleatum and Porphyromonas gingivalis [15-21]. 
Literature was searched from articles published in PubMed/MEDLINE between 2000 and 2018 using combinations of the following keywords: "bacteria", "microbiome", "oral", "oral cavity", "cancer", "carcinogenesis", "inflammation", "cytokine", "apoptosis", and "carcinogen". Titles and abstracts of found papers were examined to order to determine which articles to exclude or include in the review. From the references of included articles, additional works were selected. Finally, ninety-eight articles were included in this narrative review.

In this review, potentially oncogenic oral bacteria are presented along with the possible mechanisms of their action on carcinogenesis of human cells.

\section{Potentially Oncogenic Oral Bacteria}

Mager et al. tested 40 bacterial oral species from a group of cancer-free individuals and from a group of subjects with oral squamous cell carcinoma (OSCC). The levels of three species (Capnocytophaga gingivalis, Prevotella melaninogenica, and Streptococcus mitis) were elevated in the saliva of patients suffering from OSCC. These three bacterial species were suggested as diagnostic markers and were found to predict $80 \%$ of cancer cases [8]. Studies by Nagy et al. have shown a higher number of oral bacteria associated with keratinizing squamous cell carcinomas of the following species: Veillonella sp., Fusobacterium sp., Prevotella sp., Porphyromonas sp., Actinomyces sp., Clostridium sp., Haemophilus sp., Streptococcus spp., and Enterobacteriaceae [14].

Among streptococci, Streptococcus anginosus seems to be an especially relevant marker of head, neck, and esophageal cancers $[7,22,23]$. In studies of Sakamoto et al., oral streptococci (Streptococcus intermedius, S. constellatus, S. oralis, S. mitis, S. sanguis, S. salivarius) were the most common isolates from cervical lymph nodes in patients with oral cancer. Among the anaerobic bacteria, Peptostreptococcus spp. dominated [24]. Some papers have reported that other genera are linked with OSCCs. Lee et al. revealed significant differences between epithelial precursor lesion and cancer patients in five genera: Bacillus sp., Enterococcus sp., Parvimonas sp., Peptostreptococcus sp., and Slackia sp. [13], whereas Pushalkar et al. highly associated OSCC tumor sites with the following species: Streptococcus sp., Peptostreptococcus stomatis, Gemella sp., and Johnsonella ignava [10].

Taking the above into consideration, the most often observed oral bacteria in OSCCs are Streptococcus sp., Peptostreptococcus sp., Prevotella sp., Porphyromonas gingivalis, and Capnocytophaga gingivalis [7-13].

Oral bacteria are also detected in tumors outside the oral cavity and appear in patients with colorectal and pancreatic cancers. In cases of colorectal cancer, two species are especially prominent: Fusobacterium nucleatum and Porphyromonas gingivalis [15-17,19,25,26]. A high abundance of Fusobacterium (in particular F. nucleatum) at colorectal cancer sites has been associated with regional lymph node metastases [15] and tumor location (2\% in rectum and approx. $11 \%$ in cecum) [27]. In pancreatic cancers, in addition to Fusobacterium nucleatum and Porphyromonas gingivalis, strains of Aggregatibacter actinomycetemcomitans, Neisseria elongata, and Streptococcus mitis have been described $[18,20,21,28]$. Oral bacteria from genera Capnocytophaga and Veillonella are reportedly present in increased amounts in lung cancer patients [29].

Table 1 presents oral bacteria that are associated with specific cancer types. 
Table 1. Oral bacteria as biomarkers of specific cancer types.

\begin{tabular}{|c|c|c|c|}
\hline Cancer Localization & Oral Bacteria as Biomarkers & Main Findings & Reference \\
\hline Oral squamous cell carcinoma (OSCC) & Streptococcus anginosus & S. anginosus infection is more common in OSCC & [7] \\
\hline Oral squamous cell carcinoma (OSCC) & $\begin{array}{l}\text { Capnocytophaga gingivalis, Prevotella melaninogenica, } \\
\text { Streptococcus mitis }\end{array}$ & $\begin{array}{l}\text { Levels of mentioned bacteria were elevated in the saliva of patients } \\
\text { with OSCC }\end{array}$ & [8] \\
\hline Oral squamous cell carcinoma (OSCC) & $\begin{array}{l}\text { Bacillus, Enterococcus, Parvimonas, } \\
\text { Peptostreptococcus, Slackia }\end{array}$ & $\begin{array}{l}\text { Significant differences between epithelial precursor lesion and cancer } \\
\text { patients in presented five bacterial genera }\end{array}$ & [13] \\
\hline Oral squamous cell carcinoma (OSCC) & $\begin{array}{l}\text { Streptococcus sp. 058, S. salivarius, S. gordonii, } \\
\text { S. parasanguinis, Peptostreptococcus stomatis, Gemella } \\
\text { haemolysans, G.morbillorum, Johnsonella ignava }\end{array}$ & Presented bacteria were highly associated with OSCC tumor sites & [10] \\
\hline Oral squamous cell carcinoma (OSCC) & $\begin{array}{l}\text { Capnocytophaga gingivalis, Prevotella melaninogenica, } \\
\text { Streptococcus mitis, Porphyromonas gingivalis }\end{array}$ & $\begin{array}{l}\text { The high salivary counts of studied bacteria may be diagnostic } \\
\text { indicators of oral squamous cell carcinoma }\end{array}$ & [12] \\
\hline Gingival squamous cell carcinoma & Porphyromonas gingivalis & P. gingivalis was abundantly present in malignant oral epithelium & [9] \\
\hline Oral mucosal cancer & $\begin{array}{l}\text { Streptococcus intermedius, S. constellatus, S. oralis, } \\
\text { S. mitis, S. sanguis, S. salivarius, Peptostreptococcus sp. }\end{array}$ & $\begin{array}{l}\text { Bacteria were the most common isolates from cervical lymph nodes in } \\
\text { patients with oral cancer }\end{array}$ & [24] \\
\hline Head and neck squamous cell carcinoma (HNSCC) & Streptococcus sp. and Lactobacillus sp. & $\begin{array}{l}\text { HNSCC saliva samples were associated with increased amounts of } \\
\text { Streptococcus and Lactobacillus and a decrease in Haemophilus, Neisseria, } \\
\text { Gemella, and Aggregatibacter }\end{array}$ & [30] \\
\hline Head and neck squamous cell carcinoma (HNSCC) & Streptococcus anginosus & S. anginosus infection is implicated in the carcinogenesis of HNSCC & [22] \\
\hline Keratinizing squamous cell carcinoma & $\begin{array}{l}\text { Veillonella sp., Fusobacterium sp., Prevotella sp., } \\
\text { Porphyromonas sp., Actinomyces sp., Clostridium sp., } \\
\text { Haemophilus sp., Streptococcus sp., and } \\
\text { Enterobacteriaceae }\end{array}$ & $\begin{array}{l}\text { Higher numbers of presented bacteria in keratinizing squamous } \\
\text { cell carcinoma }\end{array}$ & [14] \\
\hline Orodigestive cancer & Porphyromonas gingivalis & $\begin{array}{l}\text { P. gingivalis is a biomarker for microbe-associated risk of death due to } \\
\text { orodigestive cancer }\end{array}$ & [31] \\
\hline Esophageal cancer & Streptococcus anginosus, S. mitis, Treponema denticola & $\begin{array}{l}\text { Studied bacteria could have a significant role in the carcinogenic } \\
\text { process by causing inflammation and by promoting the carcinogenesis }\end{array}$ & [23] \\
\hline $\begin{array}{l}\text { Esophageal adenocarcinoma and esophageal } \\
\text { squamous cell carcinoma }\end{array}$ & Porphyromonas gingivalis, Tannerella forsythia & $\begin{array}{l}\text { The abundance of } P \text {. gingivalis is trended with higher risk of } \\
\text { esophageal squamous cell carcinoma, and T. forsythia is associated } \\
\text { with higher risk of esophageal adenocarcinoma }\end{array}$ & [32] \\
\hline Colorectal cancer (CRC) & Fusobacterium sp., Porphyromonas sp. & $\begin{array}{l}\text { Increased carriage of presented bacteria was found in patients with } \\
\text { CRC; lower abundance of Clostridium sp. was simultaneously observed }\end{array}$ & [16] \\
\hline Colorectal cancer (CRC) & Fusobacterium sp. & $\begin{array}{l}\text { Fusobacterium enrichment is associated with specific molecular subsets } \\
\text { of colorectal cancers }\end{array}$ & [26] \\
\hline
\end{tabular}


Table 1. Cont

\begin{tabular}{|c|c|c|c|}
\hline Cancer Localization & Oral Bacteria as Biomarkers & Main Findings & Reference \\
\hline Colorectal cancer (CRC) & Fusobacterium sp. & $\begin{array}{l}\text { Fusobacterium sp. are enriched in human colonic adenomas. } \\
\text { F. nucleatum increases tumor multiplicity and can promote } \\
\text { tumor progression }\end{array}$ & [17] \\
\hline Colorectal cancer (CRC) & Fusobacterium nucleatum & $\begin{array}{l}\text { Patients with low } F \text {. nucleatum levels had a significantly longer overall } \\
\text { survival time than patients with moderate and high levels of the } \\
\text { bacterium }\end{array}$ & [19] \\
\hline Colorectal cancer (CRC) & Fusobacterium sp. & $\begin{array}{l}\text { Overabundance of Fusobacterium in tumor has positive association } \\
\text { with lymph node metastasis }\end{array}$ & [15] \\
\hline Colorectal cancer (CRC) & Fusobacterium sp. & Fusobacterium sequences were enriched in CRC & [25] \\
\hline Colorectal cancer (CRC) & Fusobacterium sp., Lactococcus sp. & $\begin{array}{l}\text { Presented bacteria exhibited a higher abundance in cancerous tissues, } \\
\text { while Pseudomonas and Escherichia-Shigella were reduced }\end{array}$ & {$[33]$} \\
\hline Pancreatic cancer & Porphyromonas gingivalis & $\begin{array}{l}\text { Individuals with high levels of antibodies against } P \text {. gingivalis had a } \\
\text { higher risk of pancreatic cancer }\end{array}$ & [18] \\
\hline Pancreatic cancer & $\begin{array}{l}\text { Porphyromonas gingivalis, Aggregatibacter } \\
\text { actinomycetemcomitans }\end{array}$ & $\begin{array}{l}\text { Carriage of both pathogens was associated with higher risk of } \\
\text { pancreatic cancer }\end{array}$ & [21] \\
\hline Pancreatic cancer & Fusobacterium sp. & $\begin{array}{l}\text { Level of Fusobacterium species in the tumor is associated with a worse } \\
\text { prognosis of pancreatic cancer }\end{array}$ & [20] \\
\hline Pancreatic cancer & Streptococcus mitis, Neisseria elongata & $\begin{array}{l}\text { Bacteria can be used as biomarkers for distinguishing patients with } \\
\text { pancreatic cancer from healthy subjects }\end{array}$ & [28] \\
\hline Lung cancer & Capnocytophaga sp., Veillonella sp. & $\begin{array}{l}\text { Levels of presented bacteria were significantly higher in the saliva } \\
\text { from lung cancer patients }\end{array}$ & [29] \\
\hline
\end{tabular}




\section{Mechanisms of Carcinogenic Action of Oral Bacteria}

Zhang et al. [34] suggest three mechanisms of action of oral microbiota in the pathogenesis of cancer (Figure 1). The first is bacterial stimulation of chronic inflammation. Inflammatory mediators produced in this process cause or facilitate cell proliferation, mutagenesis, oncogene activation, and angiogenesis. Regarding the second mechanism, bacteria may influence the pathogenesis of cancers by affecting cell proliferation, cytoskeletal rearrangements, activation of NF- $\mathrm{kB}$, and inhibition of cellular apoptosis. As for the third mechanism, bacteria produce some substances that may be carcinogenic [34].

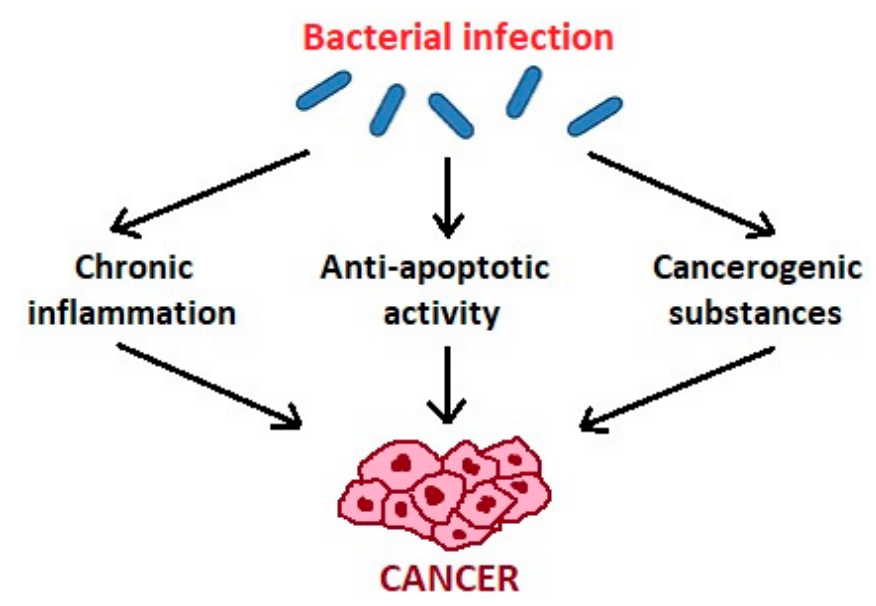

Figure 1. The influence of oral bacteria in the pathogenesis of cancer.

\subsection{Chronic Inflammatory Process}

Oral bacteria, especially anaerobic species such as Porphyromonas, Prevotella, and Fusobacterium, are responsible for periodontal diseases and lead to chronic inflammatory processes. These bacteria stimulate production of inflammatory mediators and have harmful effects on fibroblasts, epithelial and endothelial cells, and extracellular matrix components. Periodontal pathogens affect growth of local concentrations of various cytokines including interleukin-1 $\beta$ (IL-1 $\beta$ ), IL-6, IL-17, IL-23, tumor necrosis factor- $\alpha$ (TNF- $\alpha$ ), and matrix metalloproteinases MMP-8 and MMP-9 [35].

In tissues of the periodontium, monocytes/macrophages, neutrophils, fibroblasts, and mast cells are the primary sources of IL-1 $\beta$. Among others, these cells synthesize IL-1 $\beta$ in response to activation from the influence of lipopolysaccharide (LPS), the main component of Gram-negative bacteria cell walls. IL-1 $\beta$ causes osteoclast formation and bone resorption, which leads to local inflammatory changes in the periodontium. Moreover, this cytokine stimulates the release of phospholipase A2, prostaglandins (PG), acute phase proteins, as well as proinflammatory cytokine IL-6, tumor necrosis factor (TNF), and many metalloproteinases (MMPs) [36,37]. IL-1 $\beta$ activates endothelial cells to produce vascular endothelial growth factor (VEGF) and other proangiogenic factors (e.g., TNF) which provide an inflammatory microenvironment for angiogenesis and tumor progression [38]. High IL-1 $\beta$ content is associated with tumor invasiveness, migration, and more aggressive tumor phenotype $[39,40]$. In the study by Wang et al., IL-1 $\beta$ was linked to lower expression of E-cadherin, which promotes cell migration [41]. Low E-cadherin expression is correlated with disorders of cellular functions, growth inhibition, apoptosis, cell cycle arrest, and differentiation. It leads to aggressive carcinoma, higher invasiveness, and low patient survival [42,43]. Simultaneously, IL-1 $\beta$ induces MMP-9, which has a role in local extracellular matrix degradation and tumor invasion. The loss of E-cadherin-mediated adhesion and increase of MMP-9-induced migration are important markers of the transition of epithelial tumors from a benign to an invasive state [41].

Another important pro-inflammatory cytokine is IL-6. It is produced by many cells of periodontal tissues in response to stimulation under the influence of LPS and proinflammatory cytokines IL-1 $\beta$ and TNF. IL-6 induces bone resorption and stimulates synthesis of acute phase proteins, chemokines, 
and PGE2 [44,45]. IL-6 induces oxidative stress and can lead to a transient accumulation of $\mathrm{H}_{2} \mathrm{O}_{2}$ in mitochondria and consequently to mitochondrial damage [46,47]. IL-6 also affects the process of invasion and metastasis by increasing the expression of matrix metalloproteinases (MMPs) [48]. Additionally, this cytokine upregulates the expression of various adhesion molecules (ICAMs) and endothelial leukocyte adhesion molecules (ELAMs), which cause adhesion of tumor cells to endothelial cells, and therefore have an impact on tumors spreading [49]. Most genes that are targeted by IL-6 are involved in cell cycle progression and suppression of apoptosis. By influencing anti-apoptotic pathways, IL-6 may have an impact on cancer development [50].

Also, one of the major cytokines of the inflammatory response is TNF- $\alpha$. This cytokine is synthesized among others by monocytes/macrophages, neutrophils, fibroblasts, lymphocytes, and mast cells. This cytokine is secreted in response to many factors, including bacterial LPS. TNF- $\alpha$ strongly induces the production of reactive oxygen compounds, leukotrienes, prostaglandins, and metalloproteinases [51]. TNF leads to a reduction in the number of osteogenic cells and fibroblasts [52]. In contrast to high doses of TNF- $\alpha$, which are related to tumor destruction, exposure to low doses of this molecule are related to tumor promotion [53]. Activation of oncogenic signaling pathways in epithelial cells, including Wnt and NF- $\mathrm{kB}$, is critical for TNF- $\alpha$-induced tumor growth [54]. Also, TNF- $\alpha$ possesses the ability to induce DNA damage by production of reactive oxygen species [55]. TNF- $\alpha$ has been shown to influence processes of motility and invasion by induction of MMPs expression [56] and simulation of the production of various angiogenic factors, such as interleukin-8, VEGF, and basic fibroblast growth factor [57].

\subsection{Antiapoptotic Activity}

Porphyromonas gingivalis acts antiapoptotically by modulation of several pathways [58]. Intracellular $P$. gingivalis activates antiapoptotic Jak1/Akt/Stat3 signaling, which controls intrinsic mitochondrial apoptosis pathways $[59,60]$. This pathogen also accelerates progression through the S-phase of the cell cycle by manipulation of cyclin/CDK (cyclin-dependent kinase) activity and reduces the level of the p53 tumor suppressor [61]. P. gingivalis causes significant phosphorylation of pro-apoptotic Bad at the mitochondrial membrane, and its inhibition, with enhancement of the ratio of $\mathrm{Bcl} 2$ (anti-apoptotic) and Bax (pro-apoptotic). P. gingivalis inactivates pro-apoptotic Bad through Akt and simultaneously inhibits caspase-9 independently of Akt [62]. Nakhjiri et al. showed that $P$. gingivalis can inhibit apoptosis in gingival epithelial cells by upregulation of the anti-apoptotic molecule Bcl-2, whereas Bax levels were transiently elevated and then declined after $24 \mathrm{~h}$ stimulation [63]. P. gingivalis can also inhibit gingival epithelial cell apoptosis induced by ATP ligation of purinergic receptor P2X7, which plays a critical role in promoting cell growth, neovascularization, metastasis, and secretion of inflammatory cytokines. This bacterium has shown the ability to secrete an anti-apoptotic enzyme nucleoside diphosphate kinase (NDK), which cleaves ATP and prevents activation of the proapoptotic P2X7 receptor, therefore modulating ATP/P2X7-signaling [64]. Secretion of the NDK P. gingivalis can additionally modulate ATP-induced cytosolic and mitochondrial reactive oxygen species (ROS), as well as antioxidant glutathione response generated through P2X7/NADPH-oxidase interactome [65]. ROS can serve as a key mediator in the activation of transcription factors associated with inflammation and cancer development [66]. Moreover, P. gingivalis produces cysteine proteinases named gingipains, which can cleave the MMP-9 pro-enzyme, changing it into its mature active form. This process is NF-kB-dependent. Activation of MMP-9 by gingipains causes degradation of basement membrane structure, which promotes carcinoma cell migration and invasion [67]. Interactions between Porphyromonas gingivalis and epithelial cells that can affect development of oncogenic phenotype are presented in Figure 2. 


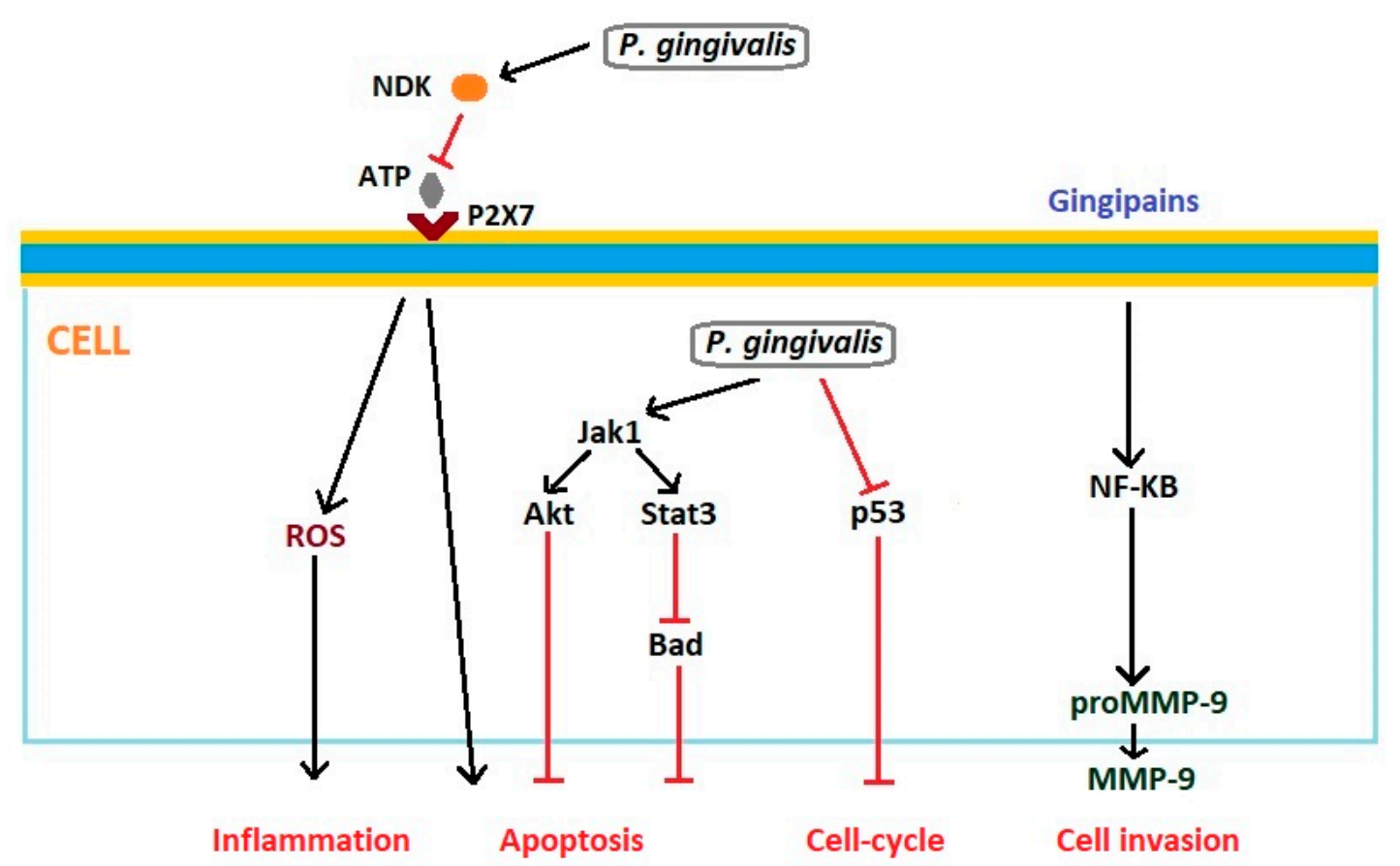

Figure 2. Interactions between Porphyromonas gingivalis and epithelial cells that can affect development of oncogenic phenotype. Based on Gholizadeh et al. [58] and Whitmore and Lamont [61]. Akt: protein kinase B; ATP: Adenosine triphosphate; Bad: Bcl-2-associated death promoter; Jak1: Janus kinase 1; MMP: metalloproteinase; NDK: nucleoside diphosphate kinase; NF-kB: nuclear factor kappa B; P2X7: Purinergic receptor; p53: Tumor protein p53; ROS: reactive oxygen species; Stat3: Signal transducer and activator of transcription 3.

Examples of Fusobacterium nucleatum LPS-activated inflammatory cytokines are include IL-1 $\beta$, IL-6, and TNF- $\alpha$. The chronic inflammatory process leads to the loss of periodontal attachment and tissue damage [68]. F. nucleatum infection modulates several antiapoptotic pathways. Bacteria induce NF-kB signaling as a consequence of Toll-like receptor (TLR) activation [69]. Of importance in the direct relationship between F. nucleatum and cancer is the fusobacterial adhesin/invasin FadA, which binds to E-cadherin on carcinoma cells and activates $\beta$-catenin signaling. This pathway results in enhanced transcriptional activity of Wnt, activation of pro-inflammatory cytokines, oncogenes, and stimulation of cancer cells proliferation [70]. FadA is a key virulence factor of $F$. nucleatum and alters macrophage infiltration and methylation of the cyclin-dependent kinase inhibitor 2A (CDKN2A) promoter in cancer lesions [71]. F. nucleatum may also activate $\beta$-catenin signaling through its LPS. In this process, the enhancement of the expression of $\beta$-catenin, and oncogenes C-myc and cyclin D1, is observed [72,73]. Additionally, F. nucleatum activates p38, resulting in the secretion of MMP-9 and MMP-13, which play very important roles in the invasion of cancer cells and metastasis [74]. Interactions between Fusobacterium nucleatum and epithelial cells that can affect the development of oncogenic phenotype are presented in Figure 3. 


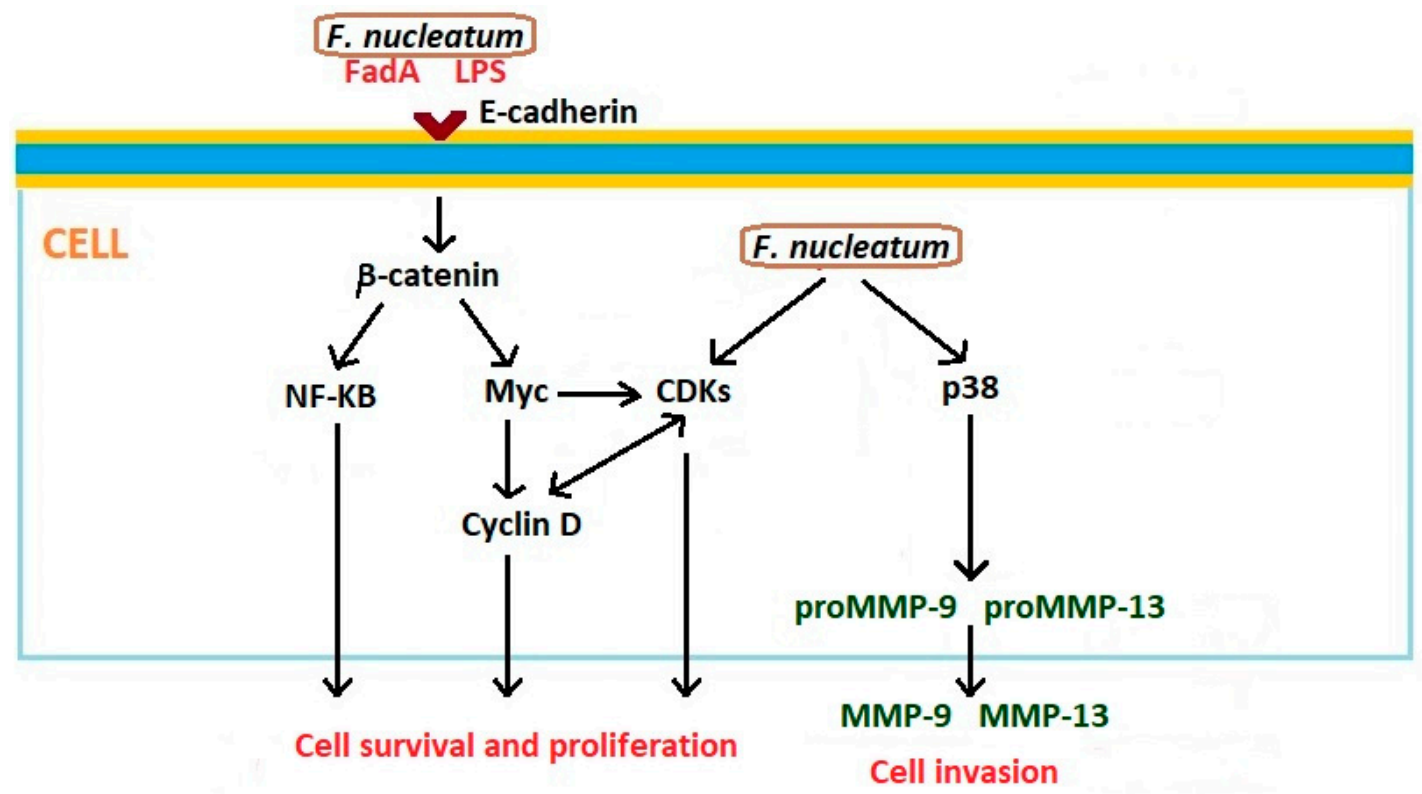

Figure 3. Interactions between Fusobacterium nucleatum and epithelial cells that can affect development of oncogenic phenotype. Based on Gholizadeh et al. [58] and Whitmore and Lamont [61]. CDK: cyclin-dependent kinase; FadA: fusobacterial adhesin/invasin; LPS: Lipopolisaccharide; MMP: metalloproteinase; NF-kB: nuclear factor kappa B; p38: Mitogen-activated protein kinase p38.

\subsection{Cancerogenic Substances}

We have little knowledge of cancerogenic substances produced by oral bacteria. Substances that may have a carcinogenic effect include the following: reactive oxygen species (ROS) and reactive nitrogen species (RNS), volatile sulfur compounds (VSC), and organic acids. The metabolization of alcohol to acetaldehyde by micro-organisms also plays an important role in the development of cancer.

During an inflammatory response, under the influence of TNF- $\alpha$, IL- 6 , and TGF- $\beta$, epithelial and immune cells trigger reactive oxygen species (ROS) and reactive nitrogen species (RNS) [75, 76]. Production of ROS and RNS occurs through induction of NADPH oxidase and nitric oxide synthase (NOS), respectively. NADPH oxidase catalyzes the superoxide anion $\left(\mathrm{O}_{2}^{-} \cdot\right.$ ) leading to superoxide dismutase-( $\left(\mathrm{SOD}^{-}\right)$-mediated hydrogen peroxide $\left(\mathrm{H}_{2} \mathrm{O}_{2}\right)$ production. Simultaneously, NOS generates nitric oxide (NO), which can be converted into nitrogen dioxide $\left(\mathrm{NO}_{2}\right)$, peroxynitrite $\left(\mathrm{ONOO}^{-}\right)$, and dinitrogen trioxide $\left(\mathrm{N}_{2} \mathrm{O}_{3}\right)$ [77]. Some species in the oral cavity involved in this process produce hydrogen peroxide $\left(\mathrm{H}_{2} \mathrm{O}_{2}\right)$. Known peroxigenic oral bacteria include: Streptococcus oralis, S. mitis, S. sanguinis, S. gordonii, S. oligofermentans [78], Lactobacillus fermentum, L. jensenii, L. acidophilus, L. minutus, and Bifidobacterium adolescentis [79]. Increased expression of NADPH oxidase, nitric oxide synthase, and their reactive oxygen and nitrogen species have been identified in various cancers. These findings support the connection of free radicals with chronic inflammation and their role in cancer development and malignant progression [80,81].

Some oral bacteria (e.g., Porphyromonas gingivalis, Prevotella intermedia, Aggregatibacter actinomycetemcomitans, and Fusobacterium nucleatum) produce volatile sulfur compounds (VSCs), such as hydrogen sulfide $\left(\mathrm{H}_{2} \mathrm{~S}\right)$, methyl mercaptan $\left(\mathrm{CH}_{3} \mathrm{SH}\right)$, dimethyl sulfide $\left(\left(\mathrm{CH}_{3}\right)_{2} \mathrm{~S}\right)$, and dimethyl disulfide $\left(\mathrm{CH}_{3} \mathrm{SSCH}_{3}\right) . \mathrm{H}_{2} \mathrm{~S}$ occurs in the highest concentration in the air inside the mouth, while in the gingival pockets the dominant compound is $\mathrm{CH}_{3} \mathrm{SH}[82,83]$. Even at low concentrations, VSCs are toxic to tissues and play a role in the pathogenesis of periodontitis and in the development of chronic inflammation [84]. $\mathrm{H}_{2} \mathrm{~S}$ is a known genotoxic agent and may lead to genomic instability or cumulative mutations [85]. Increased expression of various $\mathrm{H}_{2} \mathrm{~S}$-producing enzymes has been observed in cancer cells, particularly in cancers of the colon and ovaries. Overexpression of cystathionine- $\beta$-synthase causes the production of increased amounts of $\mathrm{H}_{2} \mathrm{~S}$, which affect tumor growth and spread by activation 
of proliferation, migration, and invasive signaling pathways, and enhance tumor angiogenesis [86]. Recently, $\mathrm{H}_{2} \mathrm{~S}$ has been found to have dichotomous effects (stimulatory and inhibitory) on several gastrointestinal processes such as inflammation, cancer, and apoptosis [87].

Some oral bacteria belonging to genera Lactobacillus, Lactococcus, Bifidobacterium, Streptococcus, Leuconostoc, and Pediococcus produce lactic acid [88]. Hooper et al. reported that most taxa isolated from within the tumor tissue of oral squamous cell carcinoma represent saccharolytic and aciduric species, mainly streptococci [89]. These microorganisms are acidogenic and aciduric, and by producing lactic acid have an influence on lowering the $\mathrm{pH}$ in the local environment [90]. Some species are capable of producing more acids (e.g., aciduric Peptostreptococcus stomatis produces acetic, butyric, isobutyric, isovaleric, and isocaproic acids) [91]. Production of such acids may contribute to the acidic and hypoxic microenvironment of tumors, thereby increasing metastatic efficiency [92,93].

Oral micro-organisms are capable of metabolizing alcohol to acetaldehyde, which is indisputably carcinogenic. Several oral microbial species such as streptococci S. gordonii, S. mitis, S. oralis, S. salivarius, S. sanguinis [94], and Candida yeasts possess the enzyme alcohol dehydrogenase (ADH), which metabolizes alcohol to acetaldehyde [95]. ADH-containing micro-organisms present a risk for carcinogenic acetaldehyde production, with subsequent potential for the development of oral cancer [96,97]. Muto et al. showed that the genus Neisseria had extremely high ADH activity and produced significant amounts of acetaldehyde in vitro. Neisseria's ability to produce acetaldehyde was more than 100-fold higher than that produced by Streptococcus sp., Stomatococcus sp., or Moraxella sp. The authors suggested that Neisseria can be a regional source of carcinogenic acetaldehyde and may thus play an essential role in alcohol-related carcinogenesis in humans [98].

\section{Conclusions}

Bacteria of the oral cavity play an important role in the development of oral, colorectal, and pancreatic cancers. The most well-confirmed is the carcinogenic effect of oral periopathogens: Fusobacterium nucleatum and Porphyromonas gingivalis. Others playing an essential role in cancerogenesis seem to be Streptococcus sp., Peptostreptococcus sp., Prevotella sp., and Capnocytophaga gingivalis. Bacteria can have an oncogenic effect on human cells in three ways: leading to chronic inflammation, acting as an antiapoptotic, and producing carcinogenic substances. However, further research is needed to clearly define specific oral bacteria as carcinogens.

Funding: This research received no external funding.

Conflicts of Interest: The author declares no conflict of interest.

\section{References}

1. Cancer. Available online: https://www.who.int/cancer/en/WorldHealthOrganization (accessed on 5 December 2018).

2. Bray, F.; Ferlay, J.; Soerjomataram, I.; Siegel, R.L.; Torre, L.A.; Jemal, A. Global cancer statistics 2018: GLOBOCAN estimates of incidence and mortality worldwide for 36 cancers in 185 countries. CA Cancer J. Clin. 2018, 68, 394-424. [CrossRef] [PubMed]

3. Oral Cancer. Available online: https://www.who.int/cancer/prevention/diagnosis-screening/oral-cancer/ en/WorldHealthOrganization (accessed on 5 December 2018).

4. Montero, P.H.; Patel, S.G. Cancer of the oral cavity. Surg. Oncol. Clin. N. Am. 2015, 24, 491-508. [CrossRef] [PubMed]

5. International Agency for Research on Cancer. Schistosomes, Liver Flukes and Helicobacter pylori. Evaluation of Carcinogenic Risks to Humans; IARC Monograph Evaluating Carcinogenic Risks to Humans; International Agency for Research on Cancer: Lyon, France, 1994; Volume 61, pp. 177-240.

6. Karpiński, T.M.; Andrzejewska, E.; Eder, P.; Linke, K.; Szkaradkiewicz, A. Evaluation of antimicrobial resistance of Helicobacter pylori in the last 15 years in West Poland. Acta Microbiol. Immunol. Hung. 2015, 62, 287-293. [CrossRef] [PubMed] 
7. Sasaki, M.; Yamaura, C.; Ohara-Nemoto, Y.; Tajika, S.; Kodama, Y.; Ohya, T.; Harada, R.; Kimura, S. Streptococcus anginosus infection in oral cancer and its infection route. Oral Dis. 2005, 11, 151-156. [CrossRef] [PubMed]

8. Mager, D.; Haffajee, A.; Devlin, P.; Norris, C.; Posner, M.; Goodson, J. The salivary microbiota as a diagnostic indicator of oral cancer: A descriptive, nonrandomized study of cancer-free and oral squamous cell carcinoma subjects. J. Transl. Med. 2005, 3, 27. [CrossRef] [PubMed]

9. Katz, J.; Onate, M.D.; Pauley, K.M.; Bhattacharyya, I.; Cha, S. Presence of Porphyromonas gingivalis in gingival squamous cell carcinoma. Int. J. Oral Sci. 2011, 3, 209-215. [CrossRef] [PubMed]

10. Pushalkar, S.; Ji, X.; Li, Y.; Estilo, C.; Yegnanarayana, R.; Singh, B.; Li, X.; Saxena, D. Comparison of oral microbiota in tumor and non-tumor tissues of patients with oral squamous cell carcinoma. BMC Microbiol. 2012, 12, 144. [CrossRef] [PubMed]

11. Atanasova, K.R.; Yilmaz, O. Looking in the Porphyromonas gingivalis cabinet of curiosities: The microbium, the host and cancer association. Mol. Oral Microbiol. 2014, 29, 55-66. [CrossRef]

12. Galvão-Moreira, L.V.; da Cruz, M.C. Oral microbiome, periodontitis and risk of head and neck cancer. Oral Oncol. 2016, 53, 17-19. [CrossRef]

13. Lee, W.H.; Chen, H.M.; Yang, S.F.; Liang, C.; Peng, C.Y.; Lin, F.M.; Tsai, L.L.; Wu, B.C.; Hsin, C.H.; Chuang, C.Y.; et al. Bacterial alterations in salivary microbiota and their association in oral cancer. Sci. Rep. 2017, 7, 16540. [CrossRef]

14. Nagy, K.N.; Sonkodi, I.; Szöke, I.; Nagy, E.; Newman, H.N. The microflora associated with human oral carcinomas. Oral Oncol. 1998, 34, 304-308. [CrossRef]

15. Castellarin, M.; Warren, R.L.; Freeman, J.D.; Dreolini, L.; Krzywinski, M.; Strauss, J.; Barnes, R.; Watson, P.; Allen-Vercoe, E.; Moore, R.A.; et al. Fusobacterium nucleatum infection is prevalent in human colorectal carcinoma. Genome Res. 2012, 22, 299-306. [CrossRef]

16. Ahn, J.; Sinha, R.; Pei, Z.; Dominianni, C.; Wu, J.; Shi, J.; Goedert, J.J.; Hayes, R.B.; Yang, L. Human gut microbiome and risk for colorectal cancer. J. Natl. Cancer Inst. 2013, 105, 1907-1911. [CrossRef]

17. Kostic, A.D.; Chun, E.; Robertson, L.; Glickman, J.N.; Gallini, C.A.; Michaud, M.; Clancy, T.E.; Chung, D.C.; Lochhead, P.; Hold, G.L.; et al. Fusobacterium nucleatum potentiates intestinal tumorigenesis and modulates the tumor-immune microenvironment. Cell Host Microbe 2013, 14, 207-215. [CrossRef] [PubMed]

18. Michaud, D.S.; Izard, J.; Wilhelm-Benartzi, C.S.; You, D.H.; Grote, V.A.; Tjønneland, A.; Dahm, C.C.; Overvad, K.; Jenab, M.; Fedirko, V.; et al. Plasma antibodies to oral bacteria and risk of pancreatic cancer in a large European prospective cohort study. Gut 2013, 62, 1764-1770. [CrossRef] [PubMed]

19. Flanagan, L.; Schmid, J.; Ebert, M.; Soucek, P.; Kunicka, T.; Liska, V.; Bruha, J.; Neary, P.; Dezeeuw, N.; Tommasino, M.; et al. Fusobacterium nucleatum associates with stages of colorectal neoplasia development, colorectal cancer and disease outcome. Eur. J. Clin. Microbiol. Infect. Dis. 2014, 33, 1381-1390. [CrossRef] [PubMed]

20. Mitsuhashi, K.; Nosho, K.; Sukawa, Y.; Matsunaga, Y.; Ito, M.; Kurihara, H.; Kanno, S.; Igarashi, H.; Naito, T.; Adachi, Y.; et al. Association of Fusobacterium species in pancreatic cancer tissues with molecular features and prognosis. Oncotarget 2015, 6, 7209-7220. [CrossRef]

21. Fan, X.; Alekseyenko, A.V.; Wu, J.; Peters, B.A.; Jacobs, E.J.; Gapstur, S.M.; Purdue, M.P.; Abnet, C.C.; Stolzenberg-Solomon, R.; Miller, G.; et al. Human oral microbiome and prospective risk for pancreatic cancer: A population-based nested case-control study. Gut 2018, 67, 120-127. [CrossRef]

22. Shiga, K.; Tateda, M.; Saijo, S.; Hori, T.; Sato, I.; Tateno, H.; Matsuura, K.; Takasaka, T.; Miyagi, T. Presence of Streptococcus infection in extra-oropharyngeal head and neck squamous cell carcinoma and its implication in carcinogenesis. Oncol Rep. 2001, 8, 245-248. [CrossRef] [PubMed]

23. Narikiyo, M.; Tanabe, C.; Yamada, Y.; Igaki, H.; Tachimori, Y.; Kato, H.; Muto, M.; Montesano, R.; Sakamoto, H.; Nakajima, Y.; et al. Frequent and preferential infection of Treponema denticola, Streptococcus mitis, and Streptococcus anginosus in esophageal cancers. Cancer Sci. 2004, 95, 569-574. [CrossRef]

24. Sakamoto, H.; Naito, H.; Ohta, Y.; Tanakna, R.; Maeda, N.; Sasaki, J.; Nord, C.E. Isolation of bacteria from cervical lymph nodes in patients with oral cancer. Arch. Oral Biol. 1999, 44, 789-793. [CrossRef]

25. Kostic, A.D.; Gevers, D.; Pedamallu, C.S.; Michaud, M.; Duke, F.; Earl, A.M.; Ojesina, A.I.; Jung, J.; Bass, A.J.; Tabernero, J.; et al. Genomic analysis identifies association of Fusobacterium with colorectal carcinoma. Genome Res. 2012, 22, 292-298. [CrossRef] [PubMed] 
26. Tahara, T.; Yamamoto, E.; Suzuki, H.; Maruyama, R.; Chung, W.; Garriga, J.; Jelinek, J.; Yamano, H.O.; Sugai, T.; An, B.; et al. Fusobacterium in colonic flora and molecular features of colorectal carcinoma. Cancer Res. 2014, 74, 1311-1318. [CrossRef] [PubMed]

27. Mima, K.; Cao, Y.; Chan, A.T.; Qian, Z.R.; Nowak, J.A.; Masugi, Y.; Shi, Y.; Song, M.; da Silva, A.; Gu, M.; et al. Fusobacterium nucleatum in colorectal carcinoma tissue according to tumor location. Clin. Transl. Gastroenterol. 2016, 7, e200. [CrossRef]

28. Farrell, J.J.; Zhang, L.; Zhou, H.; Chia, D.; Elashoff, D.; Akin, D.; Paster, B.J.; Joshipura, K.; Wong, D.T. Variations of oral microbiota are associated with pancreatic diseases including pancreatic cancer. Gut 2012, 61, 582-588. [CrossRef]

29. Yan, X.; Xinmin, Y.; Yang, M.; Liu, J.; Gao, R.; Hu, J.; Li, J.; Zhang, L.; Shi, Y.; Guo, H.; et al. Discovery and validation of potential bacterial biomarkers for lung cancer. Am. J. Cancer Res. 2015, 5, 3111-3122.

30. Guerrero-Preston, R.F.; Godoy-Vitorino, F.; Jedlicka, A.; Rodríguez-Hilario, A.; González, H.; Bondy, J.; Lawson, F.; Folawiyo, O.; Michailidi, C.; Dziedzic, A.; et al. 16S rRNA amplicon sequencing identifies microbiota associated with oral cancer, human papilloma virus infection and surgical treatment. Oncotarget 2016, 7, 51320-51334. [CrossRef]

31. Ahn, J.; Segers, S.; Hayes, R.B. Periodontal disease, Porphyromonas gingivalis serum antibody levels and orodigestive cancer mortality. Carcinogenesis 2012, 33, 1055-1058. [CrossRef]

32. Peters, B.A.; Wu, J.; Pei, Z.; Yang, L.; Purdue, M.P.; Freedman, N.D.; Jacobs, E.J.; Gapstur, S.M.; Hayes, R.B.; Ahn, J. Oral microbiome composition reflects prospective risk for esophageal cancers. Cancer Res. 2017, 77, 6777-6787. [CrossRef]

33. Gao, Z.; Guo, B.; Gao, R.; Zhu, Q.; Qin, H. Microbiota disbiosis is associated with colorectal cancer. Front. Microbiol. 2015, 6, 20. [CrossRef]

34. Zhang, Y.; Wang, X.; Li, H.; Ni, C.; Du, Z.; Yan, F. Human oral microbiota and its modulation for oral health. Biomed. Pharmacother. 2018, 99, 883-893. [CrossRef] [PubMed]

35. Szkaradkiewicz, A.K.; Karpiński, T.M. Microbiology of chronic periodontitis. J. Biol. Earth Sci. 2013, 3, M14-M20.

36. Hou, L.T.; Liu, C.M.; Liu, B.Y.; Lin, S.J.; Liao, C.S.; Rossomando, E.F. Interleukin-1 $\beta$, clinical parameters and matched cellular-histopathologic changes of biopsied gingival tissue from periodontitis patients. J. Period. Res. 2003, 38, 247-254. [CrossRef]

37. Konopka, Ł.; Brzezińska-Błaszczyk, E. Cytokines in gingival crevicular fluid as potential diagnostic and prognostic markers of periodontitis. Dent. Med. Probl. 2010, 47, 206-213.

38. Carmi, Y.; Dotan, S.; Rider, P.; Kaplanov, I.; White, M.R.; Baron, R.; Abutbul, S.; Huszar, M.; Dinarello, C.A.; Apte, R.N.; et al. The role of IL-1 $\beta$ in the early tumor cell-induced angiogenic response. J. Immunol. 2013, 190, 3500-3509. [CrossRef] [PubMed]

39. Jin, L.; Yuan, R.Q.; Fuchs, A.; Yao, Y.; Joseph, A.; Schwall, R.; Schnitt, S.J.; Guida, A.; Hastings, H.M.; Andres, J.; et al. Expression of interleukin-1beta in human breast carcinoma. Cancer 1997, 80, 421-434. [CrossRef]

40. Voronov, E.; Shouval, D.S.; Krelin, Y.; Cagnano, E.; Benharroch, D.; Iwakura, Y.; Dinarello, C.A.; Apte, R.N. IL-1 is required for tumor invasiveness and angiogenesis. Proc. Natl. Acad. Sci. USA 2003, 100, 2645-2650. [CrossRef]

41. Wang, F.M.; Liu, H.Q.; Liu, S.R.; Tang, S.P.; Yang, L.; Feng, G.S. SHP-2 promoting migration and metastasis of MCF-7 with loss of E-cadherin, dephosphorylation of FAK and secretion of MMP-9 induced by IL-1beta in vivo and in vitro. Breast Cancer Res. Treat. 2005, 89, 5-14. [CrossRef]

42. Pannone, G.; Santoro, A.; Feola, A.; Bufo, P.; Papagerakis, P.; Lo Muzio, L.; Staibano, S.; Ionna, F.; Longo, F.; Franco, R.; et al. The role of E-cadherin down-regulation in oral cancer: $\mathrm{CDH} 1$ gene expression and epigenetic blockage. Curr. Cancer Drug Targets 2014, 14, 115-127. [CrossRef]

43. Wong, S.H.M.; Fang, C.M.; Chuah, L.H.; Leong, C.O.; Ngai, S.C. E-cadherin: Its dysregulation in carcinogenesis and clinical implications. Crit. Rev. Oncol. Hematol. 2018, 121, 11-22. [CrossRef]

44. Ishimi, Y.; Miyaura, C.; Jin, C.H.; Akatsu, T.; Abe, E.; Nakamura, Y.; Yamaguchi, A.; Yoshiki, S.; Matsuda, T.; Hirano, T.; et al. IL-6 is produced by osteoblasts and induces bone resorption. J. Immunol. 1990, 145, 3297-3303. [PubMed]

45. Gabay, C. Interleukin-6 and chronic inflammation. Arthritis Res. Ther. 2006, 8, S3. [CrossRef] [PubMed] 
46. Mathy-Hartert, M.; Hogge, L.; Sanchez, C.; Deby-Dupont, G.; Crielaard, J.M.; Henrotin, Y. Interleukin-1beta and interleukin- 6 disturb the antioxidant enzyme system in bovine chondrocytes: A possible explanation for oxidative stress generation. Osteoarthr.Cartil. 2008, 16, 756-763. [CrossRef] [PubMed]

47. Murata, M.; Thanan, R.; Ma, N.; Kawanishi, S. Role of nitrative and oxidative DNA damage in inflammation-related carcinogenesis. J. Biomed. Biotechnol. 2012, 2012, 623019. [CrossRef] [PubMed]

48. Kossakowska, A.E.; Edwards, D.R.; Prusinkiewitcz, C.; Zhang, M.C.; Guo, D.; Urbanski, S.J.; Grogan, T.; Marquez, L.A.; Janowska-Wieczorek, A. Interleukin-6 regulation of matrix metalloproteinase (MMP-2 and MMP-9) and tissue inhibitor of metalloproteinase (TIMP-1) expression in malignant non-Hodgkin's lymphomas. Blood 1999, 94, 2080-2089. [PubMed]

49. Natali, P.; Nicotra, M.R.; Cavaliere, R.; Bigotti, A.; Romano, G.; Temponi, M.; Ferrone, S. Differential expression of intercellular adhesion molecule 1 in primary and metastatic melanoma lesions. Cancer Res. 1990, 50, 1271-1278.

50. Haura, E.B.; Turkson, J.; Jove, R. Mechanisms of disease: Insights into the emerging role of signal transducers and activators of transcription in cancer. Nat. Rev. Clin. Oncol. 2005, 2, 315-324. [CrossRef] [PubMed]

51. Bradley, J.R. TNF-mediated inflammatory disease. J. Pathol. 2008, 214, 149-160. [CrossRef] [PubMed]

52. Kurtiş, B.; Tüter, G.; Serdar, M.; Akdemir, P.; Uygur, C.; Firatli, E.; Bal, B. Gingival crevicular fluid levels of monocyte chemoattractant protein-1 and tumor necrosis factor- $\alpha$ in patients with chronic and aggressive periodontitis. J. Periodontol. 2005, 76, 1849-1855. [CrossRef] [PubMed]

53. Szlosarek, P.; Charles, K.A.; Balkwill, F.R. Tumour necrosis factor-alpha as a tumour promoter. Eur. J. Cancer 2006, 42, 745-750. [CrossRef] [PubMed]

54. Rivas, M.A.; Carnevale, R.P.; Proietti, C.J.; Rosemblit, C.; Beguelin, W.; Salatino, M.; Charreau, E.H.; Frahm, I.; Sapia, S.; Brouckaert, P.; et al. TNF alpha acting on TNFR1 promotes breast cancer growth via p42/P44 MAPK, JNK, Akt and NF-kappa B-dependent pathways. Exp. Cell Res. 2008, 314, 509-629. [CrossRef] [PubMed]

55. Yan, B.; Wang, H.; Rabbani, Z.N.; Zhao, Y.; Li, W.; Yuan, Y.; Li, F.; Dewhirst, M.W.; Li, C.Y. Tumor necrosis factor-alpha is a potent endogenous mutagen that promotes cellular transformation. Cancer Res. 2006, 66, 11565-11570. [CrossRef] [PubMed]

56. Leber, T.M.; Balkwill, F.R. Regulation of monocyte MMP-9 production by TNF-alpha and a tumour-derived soluble factor (MMPSF). Br. J. Cancer 1998, 78, 724-732. [CrossRef] [PubMed]

57. Yoshida, S.; Ono, M.; Shono, T.; Izumi, H.; Ishibashi, T.; Suzuki, H.; Kuwano, M. Involvement of interleukin-8, vascular endothelial growth factor, and basic fibroblast growth factor in tumor necrosis factor alpha-dependent angiogenesis. Mol. Cell Biol. 1997, 17, 4015-4023. [CrossRef] [PubMed]

58. Gholizadeh, P.; Eslami, H.; Yousefi, M.; Asgharzadeh, M.; Aghazadeh, M.; Kafil, H.S. Role of oral microbiome on oral cancers, a review. Biomed. Pharmacother. 2016, 84, 552-558. [CrossRef] [PubMed]

59. Yilmaz, Ö.; Jungas, T.; Verbeke, P.; Ojcius, D.M. Activation of the phosphatidylinositol 3-kinase/Akt pathway contributes to survival of primary epithelial cells infected with the periodontal pathogen Porphyromonas gingivalis. Infect. Immun. 2004, 72, 3743-3751. [CrossRef] [PubMed]

60. Mao, S.; Park, Y.; Hasegawa, Y.; Tribble, G.D.; James, C.E.; Handfield, M.; Stavropoulos, M.F.; Yilmaz, Ö.; Lamont, R.J. Intrinsic apoptotic pathways of gingival epithelial cells modulated by Porphyromonas gingivalis. Cell. Microbiol. 2007, 9, 1997-2007. [CrossRef]

61. Whitmore, S.E.; Lamont, R.J. Oral bacteria and cancer. PLoS Pathog. 2014, 10, e1003933. [CrossRef]

62. Yao, L.; Jermanus, C.; Barbetta, B.; Choi, C.; Verbeke, P.; Ojcius, D.; Yilmaz, Ö. Porphyromonas gingivalis infection sequesters pro-apoptotic Bad through Akt in primary gingival epithelial cells. Mol. Oral Microbiol. 2010, 25, 89-101. [CrossRef]

63. Nakhjiri, S.F.; Park, Y.; Yilmaz, O.; Chung, W.O.; Watanabe, K.; El-Sabaeny, A.; Park, K.; Lamont, R.J. Inhibition of epithelial cell apoptosis by Porphyromonas gingivalis. FEMS Microbiol. Lett. 2001, 200, 145-149. [CrossRef]

64. Yilmaz, Ö.; Yao, L.; Maeda, K.; Rose, T.M.; Lewis, E.L.; Duman, M.; Lamont, R.J.; Ojcius, D.M. ATP scavenging by the intracellular pathogen Porphyromonas gingivalis inhibits P2X7-mediated host-cell apoptosis. Cell Microbiol. 2008, 10, 863-875. [CrossRef] [PubMed] 
65. Choi, C.H.; Spooner, R.; DeGuzman, J.; Koutouzis, T.; Ojcius, D.M.; Yilmaz, O. Porphyromonas gingivalis-nucleoside-diphosphate-kinase inhibits ATP-induced reactive-oxygen-species via P2X7 receptor/NADPH-oxidase signalling and contributes to persistence. Cell Microbiol. 2013, 15, 961-976. [CrossRef] [PubMed]

66. Spooner, R.; Yilmaz, O. The role of reactive-oxygen-species in microbial persistence and inflammation. Int. J. Mol. Sci. 2011, 12, 334-352. [CrossRef] [PubMed]

67. Inaba, H.; Sugita, H.; Kuboniwa, M.; Iwai, S.; Hamada, M.; Noda, T.; Morisaki, I.; Lamont, R.J.; Amano, A. Porphyromonas gingivalis promotes invasion of oral squamous cell carcinoma through induction of proMMP9 and its activation. Cell Microbiol. 2014, 16, 131-145. [CrossRef] [PubMed]

68. Baqui, A.; Meiller, T.F.; Chon, J.J.; Turng, B.-F.; Falkler, W.A. Granulocyte- macrophage colony-stimulating factor amplification of interleukin-1b and tumor necrosis factor alpha production in THP-1 human monocytic cells stimulated with lipopolysaccharide of oral microorganisms. Clin. Diagn. Lab. Immunol. 1998, 5, 341-347.

69. Fischman, S.; Revach, B.; Bulvik, R.; Maliutina, A.; Rubinstein, A.; Nussbaum, G.; Elkin, M. Periodontal pathogens Porphyromonas gingivalis and Fusobacterium nucleatum promote tumor progression in an oral-specific chemical carcinogenesis model. Oncotarget 2015, 6, 22613-22623.

70. Rubinstein, M.R.; Wang, X.; Liu, W.; Hao, Y.; Cai, G.; Han, Y.W. Fusobacterium nucleatum promotes colorectal carcinogenesis by modulating E-cadherin/b-catenin signaling via its FadA adhesin. Cell Host Microbe 2013, 14, 195-206. [CrossRef]

71. Park, H.E.; Kim, J.H.; Cho, N.Y.; Lee, H.S.; Kang, G.H. Intratumoral Fusobacterium nucleatum abundance correlates with macrophage infiltration and CDKN2A methylation in microsatellite-unstable colorectal carcinoma. Virchows Arch. 2017, 471, 329-336. [CrossRef]

72. Chen, Y.; Peng, Y.; Yu, J.; Chen, T.; Wu, Y.; Shi, L.; Li, Q.; Wu, J.; Fu, X. Invasive Fusobacterium nucleatum activates beta-catenin signaling in colorectal cancer via a TLR4/P-PAK1 cascade. Oncotarget 2017, 8, 31802-31814. [CrossRef]

73. Wu, Y.; Wu, J.; Chen, T.; Li, Q.; Peng, W.; Li, H.; Tang, X.; Fu, X. Fusobacterium nucleatum potentiates intestinal tumorigenesis in mice via a Toll-like receptor 4/p21-activated kinase 1 cascade. Dig. Dis. Sci. 2018, 63, 1210-1218. [CrossRef]

74. Uitto, V.J.; Baillie, D.; Wu, Q.; Gendron, R.; Grenier, D.; Putnins, E.E.; Kanervo, A.; Firth, J.D. Fusobacterium nucleatum increases collagenase 3 production and migration of epithelial cells. Infect. Immun. 2005, 73, 1171-1179. [CrossRef] [PubMed]

75. Landskron, G.; De la Fuente, M.; Thuwajit, P.; Thuwajit, C.; Hermoso, M.A. Chronic inflammation and cytokines in the tumor microenvironment. J. Immunol. Res. 2014, 2014, 149185. [CrossRef]

76. Mittal, M.; Siddiqui, M.R.; Tran, K.; Reddy, S.P.; Malik, A.B. Reactive oxygen species in inflammation and tissue injury. Antioxid. Redox Signal. 2014, 20, 1126-1167. [CrossRef] [PubMed]

77. Förstermann, U.; Sessa, W.C. Nitric oxide synthases: Regulation and function. Eur. Heart J. 2012, 33, 829-837, 837a-837d. [CrossRef] [PubMed]

78. Abranches, J.; Zeng, L.; Kajfasz, J.K.; Palmer, S.R.; Chakraborty, B.; Wen, Z.T.; Richards, V.P.; Brady, L.J.; Lemos, J.A. Biology of oral streptococci. Microbiol. Spectr. 2018, 6. [CrossRef] [PubMed]

79. Brauncajs, M.; Sakowska, D.; Krzemiński, Z. Production of hydrogen peroxide by lactobacilli colonising the human oral cavity. Med. Dośw. Mikrobiol. 2001, 53, 331-336.

80. Hussain, S.P.; Hofseth, L.J.; Harris, C.C. Radical causes of cancer. Nat. Rev. Cancer 2003, 3, 276-285. [CrossRef]

81. Piao, J.Y.; Lee, H.G.; Kim, S.J.; Kim, D.H.; Han, H.J.; Ngo, H.K.; Park, S.A.; Woo, J.H.; Lee, J.S.; Na, H.K.; et al. Helicobacter pylori activates IL-6-STAT3 signaling in human gastric cancer cells: Potential roles for reactive oxygen species. Helicobacter 2016, 21, 405-416. [CrossRef]

82. Koczorowski, R.; Karpiński, T.M. Halitosis—Problem społeczny. Halitosis-A social problem. Now. Lek. 2001, 70, 657-664.

83. Koczorowski, R.; Karpiński, T.M.; Hofman, J. Badanie zależności między halitosis a chorobami przyzębia. A study of the relationship between halitosis and periodontal diseases. Dent. Forum 2004, 30, 51-56.

84. Milella, L. The negative effects of volatile sulphur compounds. J. Vet. Dent. 2015, 32, 99-102. [CrossRef]

85. Attene-Ramos, M.S.; Wagner, E.D.; Plewa, M.J.; Gaskins, H.R. Evidence that hydrogen sulfide is a genotoxic agent. Mol. Cancer Res. 2006, 4, 9-14. [CrossRef]

86. Hellmich, M.R.; Szabo, C. Hydrogen sulfide and cancer. Handb. Exp. Pharmacol. 2015, 230, $233-241$. 
87. Singh, S.B.; Lin, H.C. Hydrogen sulfide in physiology and diseases of the digestive tract. Microorganisms 2015, 3, 866-889. [CrossRef] [PubMed]

88. Karpiński, T.M.; Szkaradkiewicz, A.K. Characteristic of bacteriocines and their application. Pol. J. Microbiol. 2013, 62, 223-235. [PubMed]

89. Hooper, S.J.; Crean, S.J.; Fardy, M.J.; Lewis, M.A.; Spratt, D.A.; Wade, W.G.; Wilson, M.J. A molecular analysis of the bacteria present within oral squamous cell carcinoma. J. Med. Microbiol. 2007, 56 Pt 12, 1651-1659. [CrossRef]

90. Senneby, A.; Davies, J.R.; Svensäter, G.; Neilands, J. Acid tolerance properties of dental biofilms in vivo. BMC Microbiol. 2017, 17, 165. [CrossRef] [PubMed]

91. Downes, J.; Wade, W.G. Peptostreptococcus stomatis sp. nov., isolated from the human oral cavity. Int. J. Syst. Evol. Microb. 2006, 56, 751-754. [CrossRef] [PubMed]

92. Lunt, S.J.; Chaudary, N.; Hill, R.P. The tumor microenvironment and metastatic disease. Clin. Exp. Metastasis 2009, 26, 19-34. [CrossRef] [PubMed]

93. Mazzio, E.; Smith, B.; Soliman, K. Evaluation of endogenous acidic metabolic products associated with carbohydrate metabolism in tumor cells. Cell Biol. Toxicol. 2010, 26, 177-188. [CrossRef] [PubMed]

94. Pavlova, S.I.; Jin, L.; Gasparovich, S.R.; Tao, L. Multiple alcohol dehydrogenases but no functional acetaldehyde dehydrogenase causing excessive acetaldehyde production from ethanol by oral streptococci. Microbiology 2013, 159Pt 7, 1437-1446. [CrossRef]

95. Marttila, E.; Bowyer, P.; Sanglard, D.; Uittamo, J.; Kaihovaara, P.; Salaspuro, M.; Richardson, M.; Rautemaa, R. Fermentative 2-carbon metabolism produces carcinogenic levels of acetaldehyde in Candida albicans. Mol. Oral Microbiol. 2013, 28, 281-291. [CrossRef] [PubMed]

96. Salaspuro, M. Microbial metabolism of ethanol and acetaldehyde and clinical consequences. Addict. Biol. 1997, 2, 35-46. [CrossRef] [PubMed]

97. Meurman, J.H.; Uittamo, J. Oral micro-organisms in the etiology of cancer. Acta Odontol. Scand. 2008, 66, 321-326. [CrossRef] [PubMed]

98. Muto, M.; Hitomi, Y.; Ohtsu, A.; Shimada, H.; Kashiwase, Y.; Sasaki, H.; Yoshida, S.; Esumi, H. Acetaldehyde production by non-pathogenic Neisseria in human oral microflora: Implications for carcinogenesis in upper aerodigestive tract. Int. J. Cancer 2000, 88, 342-350. [CrossRef]

(C) 2019 by the author. Licensee MDPI, Basel, Switzerland. This article is an open access article distributed under the terms and conditions of the Creative Commons Attribution (CC BY) license (http:/ / creativecommons.org/licenses/by/4.0/). 